\title{
Metal Contaminants Occurrence and Microbial Diversity From the Perspectives of Dual Tolerance by the Bacterial Isolates Along Altitudinal Zonation of River Teesta - a Pristine River System in Eastern Himalayas
}

Upashna Chettri

North-Eastern Hill University

S R Joshi ( $\sim$ srjoshi2006@yahoo.co.in )

Northeastern Hill University https://orcid.org/0000-0003-1942-3110

\section{Research Article}

Keywords: Culturable bacterial diversity, anthropogenic factors, heavy metal tolerance, antibiotic resistance

Posted Date: December 22nd, 2021

DOl: https://doi.org/10.21203/rs.3.rs-1180701/v1

License: (c) This work is licensed under a Creative Commons Attribution 4.0 International License. Read Full License 


\section{Abstract}

The present study was conducted along River Teesta in Eastern Himalaya. Water and sediment samples were collected from six sampling points during the monsoon and winter seasons along the course of the river. The background information was collected by analysing physico-chemical parameters and the heavy metal concentrations. Culturable bacterial diversity using culture-based and molecular based 16S rRNA approaches characterized bacterial isolates to 5 major phyla, majority belonging Proteobacteria, Actinobacteria and Firmicutes followed by Bacteroidetes, AlphaProteobacteria, Beta-Proteobacteria, Gamma-Proteobacteria, Actinobacteria, Bacilli, Flavobacteriia, Deinococci, Sphingobacteriia and Cytophagia. The total of 245 characterized isolates belonged to 69 genera. Diversity indices were calculated for each site. There were variations in the community structure of culturable bacteria along the river stretch with some common and unique groups. Heavy metal tolerance and antibiotic resistance profiles showed some isolates to be tolerant to high levels of heavy metals and multiple antibiotic indicating a major concern. The antibiotic resistance diversified along the human impacted downstream sites. The present report on bacterial diversity and the associated metal and antibiotics tolerance is the first of its kind on Teesta river, the only major river system flowing through the state of Sikkim and parts of North Bengal.

\section{Introduction}

Microbial ecosystem is one of the key components of aquatic ecosystems playing important roles in various processes like biogeochemical cycling, microbial food webs, degradation of pollutants and energy flows (Guan et al. 2018). The discharge of wastewater from urban areas and industrial effluents has influenced the bacterial community composition, species abundance and their function thereby disrupting the nutrient cycling processes and negatively affecting the energy flow and loss of biodiversity. It is an established fact that the structure and function of aquatic ecosystems are facing potential threat posed by the changing global environment while the responsiveness of microbial community to the environmental variations still remains the topic of investigation and furthermore, microbial diversity in river systems is less commonly studied than the marine and lake ecosystems (Zeglin 2015). Spatial and temporal heterogeneity in bacterial diversity has been observed in various rivers driven by several environmental factors like temperature, nutrient uptake, organic matter concentration and composition, hydrology and various land use patterns (Gessner and Chauvet 1994; Valett et al. 1997; Dodds et al. 2000; Mulholland et al. 2008; Boyero et al. 2011). From the review conducted by Zeglin (2015) it was found that metal concentration in the river system was the most prominent drivers of microbial ecosystem whereas nutrients and land use were least defined. The same study also concluded that temporal variation (93\%) was more prevalent than among stream variation (86\%) or longitudinal variation (83\%) in defining the composition and structure of microbiota in lotic systems. Rivers are contaminated not only with agents like pesticides, heavy metals or pharmaceuticals but also potentially allochthonous microorganisms (Breton-Deval et al. 2019). Therefore, it is also necessary to study the response of microbes at the structure and community level and throw insights on the response of microbes to the pollutants.

The Indian rivers are not just economically important but also considered to be sacred and holds important place in Indian tradition and culture (Semwal and Akolkar, 2006). In the recent past years, with fast growing population, upsurging industrialization and various agricultural practices there has been unregulated flow of waste water into the river thereby making it vulnerable to pollution. Studies have attributed anthropogenic activities resulting in heavy metal contamination of the riverine ecosystem (Singh et al. 2017; Patel et al. 2018; Zheng et al. 2018; Bhuyan et al. 2019). Elevated levels of toxic heavy metals like $\mathrm{Hg}, \mathrm{As}, \mathrm{Pb}, \mathrm{Cd}, \mathrm{Cr}, \mathrm{Zn}$ and $\mathrm{Cu}$ have been reported from various Indian rivers (Hussain et al. 2017; Mahato et al. 2017; Singh et al. 2017; Patel et al. 2018; Rahman and Singh 2018). Heavy metals stress causes shift in bacterial community structure from native to the one dominated by more resistant and tolerant bacteria. In response to toxic concentrations of heavy metals, many aquatic organism including microorganisms can 
develop tolerance (Klerks and Weiss, 1987). Heavy metal tolerant bacteria have been isolated from polluted river system showing tolerance to copper, lead, nickel, cobalt, chromium, cadmium and mercury (Rajkumar et al. 2012; Sair et al. 2018). Studies have revealed that co-selection takes place in environmental bacteria with metal and antibiotics resistance (Wright et al. 2006; Kalayu and Ahemad, 2014). Bacteria in metal-con taminated environments have been reported to be a rich source for antibiotics resistance phenotypes than in control areas (Baker-Austin et al. 2006) and rivers are the major means of dissemination of antibiotic resistance genes which is a major public health concern.

The present study was undertaken to assess the spatial-temporal variation in the culturable bacterial diversity in surface water and sediment samples of the river Teesta, a pristine river system originating in the Eastern Himalayas which is subjected to various human intervention including several food, beverage and pharmaceutical companies and also to investigate the co-occurrence of heavy metal and antibiotic resistance among the isolates.

\section{Materials And Methods}

\section{Study area and sampling}

River Teesta, a prominent river of the Eastern Himalayan originates in the Teesta Khangse glacier located in northeastern part of Sikkim in Northeast India. The total catchment area is $12,159 \mathrm{~km}^{2}$ and is $414 \mathrm{~km}$ long with the greater part in India (151 km in Sikkim,19 km along the border between Sikkim and West Bengal, 29 km in West Bengal), 94 km along the Indo-Bangladesh border, and the final $121 \mathrm{~km}$ in Bangladesh. In terms of socio-economic development Sikkim has flourished in the past decade with various food, beverage and pharmaceutical industries that have been established along the banks of the river. In addition, Teesta has been used for power generation and has five operational hydro projects located in Sikkim and West Bengal. This has led to the destruction of vegetation and natural habitats in these areas. The sampling points and site description are depicted in Fig.1 and Table 1. Water and sediment samples were collected in presterilized containers during monsoon and winter season in the year 2018-2019 from six sampling sites along the river with the altitude ranging from $5183 \mathrm{~m}$ to $293 \mathrm{~m}$ above mean sea level. Site T1 is a tributary site between site S2 and S3. The samples were brought to the laboratory on ice condition.

\section{Background study of the sampling sites}

The physico-chemical parameters and the heavy metal concentration in the river surface water and sediment samples were determined following the standard APHA (1998) protocols.

\section{Bacterial isolation and enumeration}

Isolation of bacteria from both the sediment and water samples was done by the standard spread plate technique. In brief, 1 gram of sediment sample was suspended in $10 \mathrm{ml}$ of $0.85 \%$ saline and kept in shaking condition (150 rpm) for 1 hour. The samples were then serially diluted up to $10^{-5}$ and $0.1 \mathrm{ml}$ from each $10^{-3}, 10^{-4}$ and $10^{-5}$ dilutions were spread on Luria Bertani agar plates (composition in grams/litre: tryptone- 10, yeast extract- 5, NaCl- 10 and agar - 15). Similarly, water samples were diluted in $0.85 \%$ saline up to $10^{-4}$ fold dilution and subsequently $0.1 \mathrm{ml}$ each from $10^{-2}, 10^{-3}$ and $10^{-}$

${ }^{4}$ were plated on Reasoner's 2A or R2A agar plates (composition in grams/ litre: acicase- 0.50 , yeast extract- 0.50 , proteose peptone- 0.50 , dextrose- 0.50 , starch soluble- 0.50 , dipotassium hydrogen phosphate- 0.30 , magnesium sulfate0.024 , sodium pyruvate- 0.30 and agar- 15.0). All the media and glasswares were sterilized by autoclaving at $121^{\circ} \mathrm{C}$ for 20 minutes. The inoculated plates were incubated at $28^{\circ} \mathrm{C}$ for $24-48$ hours except for the samples from site S1 which was incubated at $10^{\circ} \mathrm{C}$ for two weeks. After incubation, colonies were selected based on their characteristic color, morphology and texture and the selected colonies were purified by streak plate technique. The cultures were cryopreserved in the cryovials with $50 \%$ glycerol at $-20^{\circ} \mathrm{C}$. Enumeration of total bacterial load was done by the standard 
plate count (SPC) technique in the form of colony forming units (CFU). The bacterial load is expressed as CFU/ml in case of water samples and CFU/grams in sediment samples.

\section{Bacterial DNA isolation and 16Sr DNA amplification}

Genomic DNA was extracted using the Bacterial genomic DNA kit by HiMedia, India. The genomic DNA was amplified targeting the 16S rRNA gene using the universal bacterial primers 27F: 5'AGAGTTTGATCCTGGCTCAG 3' and 1492R: 5'TACGGYTACCTTGTTACGACT T 3' (Weisburg et al. 1991). The amplification was carried out on a GeneAmp PCR system 9700 (Applied Biosystems, USA). Each $30 \mu$ reaction mixture consisted of $15.75 \mu$ l of milipore water, $3 \mu$ l of $10 \mathrm{X}$ buffer with $17.5 \mathrm{mM} \mathrm{MgCl}_{2}, 3 \mu \mathrm{l}$ of each forward and reverse primer of $10 \mathrm{mM}$ concentration, $2 \mu \mathrm{l}$ of dNTP mixture, $0.25 \mu \mathrm{l}$ of Taq polymerase and $3 \mu \mathrm{l}$ of template DNA. The amplified PCR products were electrophoresed on $1.2 \%$ agarose gel and purified using QIA Quick Gel Extraction Kit (Qiagen, Hilden, Germany) and sequenced at Macrogen Inc, Seoul, Korea.

\section{Sequence alignment and phylogenetic analysis}

Identification of the bacterial isolates were carried out by calculating 16S rRNA gene sequence similarity against all known procaryotic species in the Eztaxon server (Chun et al. 2007) which involves two steps. First step is the Basic Local Alignment Search Tool (BLAST) which is a sequence similarity search program was used to compare our query sequence to the sequence database of the National Centre for Biotechnology Information (Altschul et al. 1990) and secondly, pairwise sequence alignment to find out sequence similarity between the query sequence and hit sequences obtained in the first step. This algorithm uses $98.65 \%$ similarity threshold as species boundary. Before phylogenetic analysis, the sequences obtained from sanger sequencing were trimmed by the help of Molecular Evolutionary Genetics Analysis software, MEGA 7.0 (Tamura et al, 2011) and the sequences were aligned by using the clustal W inbuilt in MEGA 7.0 where the most similar sequences with best alignment score are aligned first followed by more distant groups and a phylogenetic tree was constructed using the neighbor-joining method (Saitou and Nei, 1987) with 1000 bootstrap replications to assess nodal support in the tree (Felsenstein, 1981). The nucleotide sequences were submitted to NCBI and the accession numbers were obtained.

\section{Diversity analysis}

With a view to compare the culturable bacterial diversity in both the water and sediment samples, samples were analysed both spatially and temporally in order to understand the effect of altitude gradient, human intervention and seasonal fluctuations. Diversity analysis was assessed by calculating Shannon-Weiner diversity index (H), Simpson's dominance index (D), evenness index (E) and richness index by Margalef.

\section{Determination of MIC (Minimum Inhibitory Concentration) of the bacterial isolates against heavy metals}

MIC of the bacterial isolates was determined against four heavy metals $\mathrm{Pb}, \mathrm{Zn}, \mathrm{Cu}$ and $\mathrm{Cd}$ by spot plate technique. Stock solutions of the metals were obtained from the metal salts of $\mathrm{ZnSO}_{4} \cdot \mathrm{H}_{2} \mathrm{O}, \mathrm{Pb}\left(\mathrm{NO}_{3}\right)_{2}, \mathrm{CuSO}_{4} \cdot 5 \mathrm{H}_{2} \mathrm{O}$ and $\mathrm{Cd}\left(\mathrm{NO}_{3}\right)_{2}$ purchased from Sigma Aldrich to obtain stock solution of $10,00 \mathrm{ppm}$. Heavy metal containing plates were prepared by supplementing Luria Bertani agar with various concentrations of heavy metals ranging from 50 to 2000 ppm in case of $\mathrm{Pb}, \mathrm{Zn}$ and $\mathrm{Cu}$ and $\mathrm{Cd}$ was used at the concentration ranging from 1-100 ppm. The isolates were grown overnight in Luria Bertani broth and $10 \mu \mathrm{l}$ of the culture corresponding to OD 0.5 at $600 \mathrm{~nm}$ was spotted on the metal containing plates and incubated at $28^{\circ} \mathrm{C}$ for $24 \mathrm{~h}$. MIC was determined as the lowest concentration of metal that inhibited growth after $24 \mathrm{~h}$. 
The antibiotic susceptibility of the bacterial isolates was conducted using agar diffusion technique on Mueller-Hinton agar (MHA) plates following the guidelines of the Clinical Laboratory standard Institue (CLSI) 2013. In the present study total 15 antibiotics was used which are as follows Meropenem $(10 \mathrm{mcg})$, Imipenem $(10 \mathrm{mcg})$, Erythromycin $(10 \mathrm{mcg})$, Ciprofloxacin (5mcg), Nalidixic acid (30 mcg), Netillin (30 mcg), Novobiocin (30mcg), Neomycin (30mcg), Tigecycline (15mcg), Lincomycin (15mcg), Rifampicin (5mcg), Polymyxin B (300U), Co- Trimoxazole (25mcg), Ceftazidime (30mcg), Trimethoprim (5mcg) using standard antibiotic discs (HiMedia, India). The multiple antibiotic resistance (MAR) index for the test isolates was calculated as $a / b$ where $a$ represents the number of antibiotics the isolates is resistant to and $b$ represents the total number of antibiotics used against the isolate (Krumperman 1983). A MAR index value of $>0.2$ indicates that the isolate is multiple antibiotic resistant whereas a MAR index value of $<$ or $=0.2$ indicates a very low or negligible antibiotic resistance.

\section{Statistical analysis}

PAST 4.07b software was used for conducting all the statistical analysis including the calculation of diversity indices and preparing graphs. Pearson's correlation was employed to understand the relationship between various physicochemical properties and the culturable microbial taxa in both the water and sediment samples.

\section{Results And Discussion}

\section{Physico-chemical parameters of river water and sediment samples}

The mean values along with the standard deviation of the various physico-chemical parameters are presented in the Table 2. The temperature of the river water ranged from $2^{\circ} \mathrm{C}$ to $19{ }^{\circ} \mathrm{C}$ where the lowest temperature was recorded at site S1 during winter. The mean values of all the parameters were found to be below the permissible limit of BIS 2012 . However, BOD was slightly higher at site S3 followed by site S5 and T1. The determined DO at S1 is lower than the other sites because of the high altitude with low atmospheric oxygen.

The estimation of $\mathrm{Pb}, \mathrm{Zn}, \mathrm{Cu}$ and $\mathrm{Cd}$ were carried out in both the water and sediment samples. The mean concentration of the metals for the analysed samples are presented in Table 3. The concentration of $\mathrm{Pb}$ in the water samples from the sites S4, S5 and T1 slightly crossed the permissible limit of BIS during both monsoon and winter seasons whereas other heavy metals were found to be below the threshold range of BIS. In the sediment samples, the concentrations of heavy metals were found be several orders of magnitude higher than the water samples. The mean concentration of $\mathrm{Pb}$ in the downstream sites S4, S5 and T1 ranged from 12.5 -27.4 ppm which surpassed the limit of BIS which is $11 \mathrm{ppm}$. The concentration of $\mathrm{Zn}$ ranged from $1.8 \mathrm{ppm}$ to $85.6 \mathrm{ppm}$ and the concentration was found to exceed the BIS limit of 16 $\mathrm{ppm}$ in the monsoon season as compared to winter season. this elevated levels of heavy metals in the downstream sites could be the effect of industrialization.

Mann-Whitney U test, was employed due to skewness of data to find out for any seasonal variations in the heavy metal concentrations in monsoon and winter season. The test revealed no significant differences in the heavy metal concentrations in monsoon and winter season for water samples. In case of sediment samples we see significant difference in concentration of $\mathrm{Zn}\left(\mathrm{t}_{\mathrm{df}(10)}=7.477, \mathrm{p}<0.01\right)$ and $\mathrm{Cu}\left(\mathrm{t}_{\mathrm{df}(10)}=3.533, \mathrm{p}<0.01\right)$ between the two seasons which showed that both the concentration of $\mathrm{Zn}$ and $\mathrm{Cu}$ decreased significantly in winter season at various sites. However, no significant differences were observed in concentrations of $\mathrm{Pb}$ and $\mathrm{Cd}$ between the two seasons.

\section{Total viable count}

Out of the water and sediment samples, rich bacterial load was shown by the sediment samples which was expressed as CFU/g than the water samples depicted in Table 4. The mean bacterial load was highest in site S4 and lowest in S1 
in both the water sample and sediment respectively. Less bacterial load at S1 could be explained by the high altitude of S1, cold and oligotrophic environment. From ANOVA, the variation in bacterial load between different sites was highly significant in both the water sample $\left(F_{d f(5)}=35.16, p<0.01\right)$ and sediment $\left(F_{d f(5)}=5.42, p<0.01\right)$ as well. However, the ttest showed no significant seasonal variation in the mean bacterial load in both the water samples $\left(t_{d f(10)}=1.954, p=\right.$ .079 ) and sediment samples $\left(t_{d f(10)}=-.889, p=.395\right)$. In the present study, bacterial load was higher in the downstream sites which could be explained by the waste water discharge close to the sites thereby increasing the organic matter which supports bacterial growth. On the basis of colony morphology total 129 and 116 bacterial isolates were obtained both from water and sediment samples during monsoon and winter season respectively.

\section{Culturable bacterial diversity of river water and sediment samples}

Based on the colony morphology and 16S rRNA gene sequencing a total of 129 isolates (water-86 and sediment-43) and 116 isolates (water-61 and sediment-55) were recovered in monsoon season and winter season respectively making a total of 245 isolates. The bacterial isolates belonged to 5 major phyla with the higher percentage of the bacterial isolates belonging to major phyla like the Proteobacteria, Actinobacteria and Firmicutes followed by Bacteroidetes and Deinococcus-Thermus. These phyla were represented by various classes belonging to Alpha-peoteobacteria, Betapeoteobacteria, Gamma-proteobacteria, Actinobacteria, Bacilli, Flavobacteriia, Deinococci, Sphingobacteriia and Cytophagia. Representative comparison of different phyla and classes in both water and sediment samples are shown in Fig 2 and Fig 3. In the water samples Proteobacteria and Actinobacteria were dominating phyla in all the sites during both monsoon and winter season. Firmicutes were found to be prevalent during monsoon season than in winter at all the sites. Deinococcus-Thermus was a unique phylum that was detected only at site S5 which represented $5 \%$ of the total phyla at that particular site. The common classes present in water samples during both the seasons are the Alphaproteobacteria, Beta-proteobacteria, Gamma-proteobacteria and Bacilli. Flavobacteriia and Deinococci was detected only during monsoon season whereas Sphingobacteriia and Cytophagia were two unique classes found only at site S1.

In the sediment samples, Proteobacteria, Actinobacteria and Firmicutes are the phyla commonly present in all the sites during both monsoon and winter season. Deinococcus-Thermus was present only at site S4 in monsoon season whereas in winter season Bacteroidetes was present only at site S1. At the class level, Alpha-proteobacteria, Betaproteobacteria and Gamma-proteobacteria, Bacilli and Actinobacteria are commonly present. Flavobacteriia was detected only at site S1 in both the seasons whereas Deinococci was found only in monsoon season present only at site S4.

\section{Bacterial diversity at the genus level}

From all the samples with 244 total isolates, a total of 69 genera were identified after comparing the $16 \mathrm{~S}$ rRNA sequence with the known sequences deposited in the public database EzBioCloud, https://www.ezbiocloud.net/identify. The spatio-temporal comparison of the various genera isolated from water and sediment samples are provided in the Fig 3. The isolates exhibited $>97 \%$ to the previously deposited sequences. High bacterial diversity was displayed by both the water and sediment samples. The recovered bacterial genera were higher in the water samples as compared to the sediment samples.

In case of water samples, out of 138 identified genera some of the genera prevalent in the water samples in more than two sites are Pseudomonas (13\%) followed by Microbacterium (5.79\%), Bacillus (5\%), Acinetobacter (5\%), Brevundimonas (4.34\%), Serratia (3.6\%) Arthrobacter (2.8\%), Janibacter (2.8\%), and that altogether accounted for $42.33 \%$ of the total isolates identified in the water samples and the rest $57.67 \%$ isolates represented genera that were uniquely present at less than two sites. Genera like Flavobacterium, Duganella, Pedobacter, Deefgea, Arcicella were present only at site S1 belonging to the phylum Bacteroidetes and Proteobacteria. Genera distinct to site S2 are 
Haemophilus, Ideonella, Roseateles and Variovorax whereas Phycicoccus, Nocardioides, Asticcacaulis and Vogesella were unique only to site S3. Myroides and Comamonas were found to be present only at site S4 and Priestia, Deinococcus, Phenylobacteium and Brucella were unique to site S5 and similarly Demacoccus, Agromyces and Gordonia were unique genera present only at site T1. The dowmstream sites impacted by human intervention were represented more by the opportunistic pathogens like Serratia, Acinetobacter, Pseudomonas, Microbacterium, Gordonia. and Brucella. Water is an easy means of dissemination of these pathogens and these bacteria can easily come in contact with the humans when the water is used for various purposes including recreation.

In the sediment samples, total 95 genera were identified amongst which Pseudomonas (11.57\%) was prevalent in more than two sites followed by Microbacterium (10.5\%), Acinetobacter (8.4\%) and Arthrobacter (6.3\%) accounting for 36.9\% of the total isolates in the sediment samples and the remaining $60.1 \%$ accounted for the less prevalent genera. Cryobacterium was found only in the site $\mathrm{S} 1$ which is characterised by high altitude and cold temperature throughout the year. Comamonas was identified only from the samples of site S2 and Deinococcus was found to be present only at site S4 and Hydrogenophaga, Paracoccus and Ensifer were unique genera found at site T1.

\section{Diversity analysis}

Diversity indices are calculated to compare the community richness and evenness within the various sampling sites and seasons. Shannon-Weiner and Simpson's index gives idea about community composition. Shanno-Weiner index puts more weight on species richness whereas the Simpson's index considers species evenness (Kim et al. 2017). The Shannon richness in water samples ranged from 1.76-2.91 and 1.96-2.74in monsoon and winter respectively. Similarly in the sediment samples, the Shannon index ranged from 1.03-2.29 and 1.38 -2.47 in monsoon and winter respectively. Shannon index values showed that the bacterial diversity was comparatively higher in the water samples as compared to the sediment samples which is also apparent from the Shannon rarefaction curve (Fig. 4). In case of water samples, bacterial diversity as indicated by the Shannon index increased as we go downstream but however no such observation was found in the case of sediment samples. The Simpson's index ranged from 0.77-1 and 0.89-1 respectively in monsoon and winter season in the water sample. In the sediment samples the values ranged from 0.6-0.95 in monsoon and 0.75-0.96 in winter season. The Margalef's richness index for water samples ranged from 2.16-4.50 in monsoon and 1.37-2.89 in winter. According to the Margalef's index calculated for the water samples high bacterial richness was observed at site S5 (downstream site) and least at site S1 (uppermost site). Similarly, in the case of the sediment samples the values ranged from 1.12-2.92 in monsoon and 1.37-3.22 in winter samples with the bacterial richness least in the upstream sites and highest in the downstream sites except for site S5 which showed less Margalef value in winter. This richness at particular sites in the river could possibly be due to its ability to grow at particular environmental conditions which are enriched by inputs from human intervention. In addition, the culturable bacterial diversity are limited to those bacteria which can grow in the provided media and given conditions therefore the relative abundance provided by the culturable bacteria does not provide a clear picture of the microbial community like the culture independent approaches (Venkatachalam et al. 2015). The summary of various diversity indices in water and sediment samples are given in Table 5. Shannon diversity index was used to study any seasonal variation and the t-test analysis showed no significant variation in diversity between seasons (monsoon vs winter) in both the water samples $\left(t_{d f(10)}=\right.$ $.624), p=.547)$ and sediments $\left(t_{d f(10)}=-.452, p=.661\right)$ respectively.

\section{Accession numbers for the isolates}

Accession numbers for all 245 isolates were obtained after submission of 16S rRNA sequences to the NCBI database https://www.ncbi.nlm.nih.gov/ . The accession numbers of the isoaltes are as follows: MN726744MN726749; MN727110-MN727116; MN733078-MN733085; MN733101-MN733106; MN733214-MN733218; MN733329MN733339; MN726750- MN726753; MN727117-MN727130; MN733086-MN733122; MN733219-MN733240; 
MN733340-MN733354; OK090491-OK090506; OK090511-OK090522; OK090551- OK090569; OK090524-OK090545; OK090595-OK090618; OK090572-OK090594.

\section{Correlation analysis}

Relationship between species richness and bacterial load with the various physico-chemical parameters

The species diversity and bacterial load in the water samples showed a positive correlation with each other ( $r=.690$, $\mathrm{p}<0.05)$. Among all the physico-chemical parameters only temperature and Cu concentration showed a positive correlation with the species diversity (Table 6) whereas bacterial load in the water samples showed a positive association with temperature and concentrations of all the heavy metals. Species diversity did not show any significant relationship with the heavy metal concentration in the sediments. However, the bacterial load was positively correlated to $\mathrm{Pb}(r=.664, \mathrm{p}<0.05)$ and $\mathrm{Cd}(\mathrm{r}=.813, \mathrm{p}<0.001)$ concentrations (Table 7).

Pearson's analysis was conducted to check for the relationship of the various physico-chemical parameters and bacterial classes. For the water samples, the analysis showed that temperature showed significant $(p<0.05)$ positive correlation to the dissolved oxygen and bacterial load whereas it showed significant negative correlation with the abundance of Sphingobacteria and Cytophagia. Similarly, DO was found to have significant positive correlation with the bacterial load and Deinococci abundance. TDS and conductivity were found to be significant variable with respect to Actinobacteria (positive correlation) and y-Proteobacteria (negative correlation) as depicted in Fig. 5. Heavy metals like $\mathrm{Pb}$ and $\mathrm{Cd}$ positively correlated with the bacterial load, $\mathrm{Zn}$ showed strong positive correlation with $\mathrm{Cu}$ and $\mathrm{Cd}$ and with the abundance of Bacilli. In one study from metal polluted area, it was found that Bacillus sp. was the most dominant and frequently isolated species which indicates its potential to survive in metal polluted areas and could be an indicator of metal contaminated areas (Zampieri et al 2016).

In the case of sediment samples, $\mathrm{Pb}$ and $\mathrm{Cd}$ showed significant positive correlation with the bacterial load and $\mathrm{Pb}$ further showed positive correlation with Deinococci. Increased heavy metals have showed higher relative abundance of abundances of Deinococci in metal exposed areas. Similarly, Zn and Cu were found to be strongly positively correlated and both metals demonstrated moderate positive correlation with $\beta$-Proteobacteria (Fig. 5).

\section{Heavy metal tolerance of the isolates}

In this study, total 107 bacterial isolates were tested for their tolerance to four heavy metals $\mathrm{Pb}, \mathrm{Zn}, \mathrm{Cu}$ and $\mathrm{Cd}$ and the MIC values were recorded. MICs are crucial in understanding the response of the bacterial isolates to the heavy metals and could be associated with the heavy metal concentration and toxicity (Zampeiri et al 2016).

The tolerance of the isolates to the heavy metals showed varying trend depending upon the sampling sites (Table 8). The MIC of $\mathrm{Pb}$ ranged from $500-2000$ ppm where about $82 \%$ of the isolates belonging to the downstram sites showed MIC values 2000 ppm. The MIC values of Zn ranged from 100-1000 ppm, 6.5\% of total isolates displayed MIC of 100 ppm, 38\% showed MIC of 250 ppm, 42\% showed MIC of 500 ppm and remaining 13\% showed MIC of $1000 \mathrm{ppm}$. In the case of $\mathrm{Cu}$ the MIC of the isolates ranged from 250-1000 ppm with 25\% showing MIC value of 250, 67\% displayed MIC of $500 \mathrm{ppm}$ and the remaining $8 \%$ showed MIC of $1000 \mathrm{ppm}$. Considering the background values for Cd determined in the study sites which ranged from 0.02-1.2, concentartion od Cd was used at lower concentration ranging from 1-100 ppm. The MIC of the isolated ranged from 2.5-100 ppm where $2 \%$ isolated shoed MIC between $2.5-5 \mathrm{ppm}, 26 \%$ of the isolates showed MIC of 10 ppm, 38\% had MIC of 50 ppm and the remaining 44\% showed MIC of 100 ppm. The degree of tolerance of the isolates to the heavy metals were as follows $\mathrm{Pb}>\mathrm{Zn}>\mathrm{Cu}>\mathrm{Cd}$. 
All 107 isolates were tested for antimicrobial resistance against 15 antibiotics belonging to various classes of antibiotics. The number of isolates showing resistance to various classes of antibiotics are summarised in Table 9 and percentage wise graphical representation is shown in Fig 6. which also indicates that the frequency of the antibiotics to which bacterial isolates are resistant to increases as we move from upper stretch to lower stretch which has more human impact in terms of anthropogenic input in to the river. Considering the number of antibiotics an isolate is resistant to, MAR (multiple antibiotic resistant) index was calculated for each isolate. The MAR index range for each site and the percentage of MAR bacteria at each site is presented in the Table 10 .

The MAR index at site S1 ranged from 0.13-0.2, at S2 it ranged from 0-0.46, followed by S3 that ranged from 0.2-0.53, at S4 it ranged from $0.13-0.53$, TS5 showed $0.2-0.46$ and finally at T1 it ranged from 0.13-0.53. An increase in the number of isolates showing multiple antibiotic resistance was observed at the downstream sites (Table 10). Highest percentage of isolates $92 \%$ and $95 \%$ was observed at sites S4 and S5 respectively. S4 is a site characterised by human settlement and several pharmaceutical companies along the banks of the river and S5 is a site downstream to S4 The percentage of MAR bacteria increased downstream along the length of the river (Table 10).

Amongst the various isolates tested for resistance to antibiotics, Pseudomonas and Acinetobacter showed the highest MAR values that ranged from 0.2-0.6 and 0.2-0.53 respectively followed by Bacillus for which MAR index ranged from 00.46 and Paenarthrobacter showed 0.4 MAR index. All the Serratia and Microbacterium isolates showed MAR index of 0.33 and for Stenotrophomonas the values ranged from 0.26-0.33 whereas Brevundimonas and Arthrobacter showed MAR index range from 0.13-0.33 and Exiguobacterium and Brevibacterium showed 0.26 MAR index and least of values of 0.2 was shown by Cryobacterium andJanibacter whereas Kocuria and Flavobacterium showed only 0.13 MAR index value. The presence of heavy metals in the environment causes selective pressure leading to increase in bacterial resistance to heavy metals and antibiotics. Metals like $\mathrm{Pb}, \mathrm{Zn}, \mathrm{Cu}$ and $\mathrm{Cd}$ have huge applications in industries and also enter the environment via various vehicular emissions, batteries, mining activities and gasoline spillage (Mahato et al 2017) these heavy metals are known to increase the concentrations of selected antibiotic resistance genes (Li et al 2019). The spread of antibiotic resistance can occur between related and unrelatind bacteria including pathogenic and non-pathogenic ones. Mobile genetic elements such as plasmids and integrons encoding the antibiotic resistance genes are spread in the microorganisms through horizontal gene transfer as a result of which resistance genes are disseminated in the environment and water is an easy means of dissemination (Khan et al 2013).

\section{Conclusion}

This study showed that the levels of heavy metas like $\mathrm{Pb}$ and $\mathrm{Zn}$ at certain human impacted areas to be elevated as compared to the other sites. The bacterial load showed significant variations among the sites with higher load at the downstream sites possibly explained by the anthropogenic organic matter input from adjoining industrial and domestic areas. Bacterial diversity was higher in the water samples however our study found that there was no effect of season on the diversity. Heavy metals alter the bacterial composition and function and here we isolated bacterial strains showing tolerance to both heavy metals and antibiotics and the MAR bacteria increased in the downstream sites.

\section{Declarations}

Acknowledgement: Authors acknowledge the financial support received from govt. of India through DST-FIST [SR/FST/ LSI-666/2016(C)] and UGC-SAP [F.4-7/2016/DRS-1 (SAP-II)] to the parent department.

Funding: Authors acknowledge the financial support received from govt. of India through DST-FIST [SR/FST/ LSI666/2016(C)] and UGC-SAP [F.4-7/2016/DRS-1 (SAP-II)] to the parent department. 
Conflict of interest/ Competing interests: The authors declare no competing interest.

Author contributions: SRJ conceived the study. UC conducted the experiments. SRJ and UC wrote the manuscript and anlsysed the data.

Availability of data material: The study did not involve any data deposition

\section{Code availability: NA}

Ethics approval: The study did not require any ethical clearances to conduct the study.

Consent to participate: Authors declare their consent to participate in the present work.

Consent for publication: Both the authors have consented to publication of the present research findings.

Permission: Necessary permission to carry out the study as per the existing regulations was obtained from Department of Forest, environment and Wildlife Management, Office of the Chief Conservator of Forest (T\&HQ) cum CWLW, Govt of Sikkim, India.

\section{References}

Altschul SF, Gish W, Miller W, Myers EW, Lipman DJ (1990) Basic local alignment search tool. J Mol Biol 215(3): 403-10 APHA. (1998). Standard methods for examination of water and wastewater. Washington: American Public Health Association

Baker-Austin, C., Wright, M.S., Stepanauskas, R. and McArthur, J.V. (2006). Co-selection of antibiotic and metal resistance. Trends in Microbiology 14, 76-182

Bhuyan MS, Bakar MA, Rashed-Un-Nabi M, Senapathi V, Chungs SY, Islam MS (2019) Monitoring and assessment of heavy metal contamination in surface water and sediment of the Old Brahmaputra River, Bangladesh. Appl Water Sci 9:125. https://doi.org/10.1007/s13201-019-1004-y

BIS (2012). Drinking water specification. Bureau of Indian Standard, New Delhi IS: 10500

Boyero L, Pearson RG, Gessner MO, Barmuta LA, Ferreira V, Graca MAS et al (2011) A global experiment suggests climate warm- ing will not accelerate litter decomposition in streams but might reduce carbon sequestration. Ecol Lett 14: 289-294. doi:10.1111/j.1461-0248.2010. 01578.x

Chun, J., Lee, J. H., Jung, Y., Kim, M., Kim, S., Kim, B. K., et al. (2007). EzTaxon: A webbased tool for the identification of prokaryotes based on 16S ribosomal RNA gene sequences. Int J Syst Evol Microbiol 57:2259-2261

CLSI (Clinical and Laboratory Standards Institute) (2013) Performance standards for antimicrobial susceptibility testing, M100-S23. Clinical and Laboratory Standards Institute, Wayne, 1-59

Dodds WK, Lopez AJ, Bowden WB, Gregory S, Grimm NB, Hamilton SK et al. (2000) N uptake as a function of concentration in streams. J North Am Benthol Soc 21: 206-220. doi:10.2307/1468410

Felsenstein J. (1981). Evolutionary trees from DNA sequences: a maximum likelihood approach. J Mol Evol17:368-376

Gessner MO, Chauvet E (1994) Importance of stream microfuge in controlling breakdown rates of leaf litter.

Ecology 75:1807-1817. doi:10.2307/1939639

Page $10 / 24$ 
Guan Y, Jia J, Wu L, Xue X, Zhang G, Wang Z (2018) Analysis of bacterial community characteristics, abundance of antibiotics and antibiotic resistance genes along a pollution gradient of Ba river in Xi'an, China. Front. Microbiol 9: 31913203

Hussain J, Husain I, Arif M, Gupta N (2017). Studies on heavy metal contamination in Godavari river basin. Appl Water Sci 7:4539- 4548

Kalayu G, Ahemad M (2014) Incidence of heavy metal and antibiotic resistance in bacterial isolates from Blue Nile river water in Ethiopian region. Int J Environ Sci 71:546-569

Khan GA, Berglund B, Khan KM, Lindgren PE, Fick J (2013) Occurrence and abundance of antibiotics and resistance genes in rivers, canal and near drug formulation facilities - A Study in Pakistan. PLoS ONE 8: 62712-62720

Klerks PL, Weis JS (1987) Genetic adaptation to heavy metals in aquatic organisms: A review. Environ Pollut 45, 173205

Krumperman, P.H. (1983) Multiple Antibiotic Resistance Indexing of Escherichia coli to Identify High-Risk Sources of Fecal Contamination of Foods. Appl. Environ. Microbiol 46: 165-170

Li X, Gu AZ, Zhang Y, Xie B, Li D, Chen J (2019) Sub-lethal concentrations of heavy metals induce antibiotic resistance via mutagenesis. J Hazard Mater 369: 9-16. https://doi.org/10.1016/j.jhazmat.2019. 02.006 PMID: 3075395639.

Mahato MK, Singh G, Singh PK, Singh AK, Tiwari AK (2017). Assessment of Mine Water Quality Using Heavy Metal Pollution Index in a Coal Mining Area of Damodar River Basin, India. Bull Environ Contam Toxicol 99(1):54-61. doi: 10.1007/s00128-017-2097-3.

Mahato MK, Singh G, Singh PK, Singh AK, Tiwari AK (2017) Assessment of Mine Water Quality Using Heavy Metal Pollution Index in a Coal Mining Area of Damodar River Basin, India. Bull Environ Contam Toxicol. 99(1):54-61. doi: 10.1007/s00128-017-2097-3.

Mulholland PJ, Helton AM, Poole GC, Hall RO, Hamilton SK, Peterson BJ et al (2008) Stream denitrification across biomes and its response to anthropogenic nitrate loading. Nature 452: 202-205. doi:10.1038/nature06686

Patel P, Raju NJ, Reddy BCSR, Suresh U, Sankar DB, Reddy TVK (2018) Heavy metal contamination in river water and sediments of the Swarnamukhi River Basin, India: risk assessment and environmental implications. Environ Geochem Health 40(2):609-623. doi: 10.1007/s10653-017-0006-7

Rahman Z, Singh VP (2018) Assessment of heavy metal contamination and Hg-resistant bacteria in surface water from different regions of Delhi, India. Saudi J Biol Sci 25(8):1687-1695. doi: 10.1016/j.sjbs.2016.09.018

Rajkumar B, Sharma GD, Paul AK (2012) Isolation and characterization of heavy metal resistant bacteria from Barak river contaminated with pulp paper mill effluent, South Assam. Bull Environ ContamToxicol 89:263-268

Sair AT, Khan ZA (2018) Prevalence of antibiotic and heavy metal resistance in Gram negative bacteria isolated from rivers in northern Pakistan. Water Environ J 32:51-57

Saitou N, Nei M (1987) The neighbor-joining method: A new method for reconstructing phylogenetic trees. Mo Biol Evol $4: 406-425$

Semwal N, Akolkar P (2006) Water quality assessment of sacred Himalayan Rivers of Uttarakhand. Curr Sci 91: 486496

Page $11 / 24$ 
Singh H, Pandey R, Singh SK, Shukla DN (2017) Assessment of heavy metal contamination in the sediment of the River Ghaghara, a major tributary of the River Ganga in Northern India. Appl Water Sci 7:4133-4149

Subramanian V, Sitaswad R, Abbas N, Jha PK (1987) Environmental geology of the Ganga River basin. J Geol Soc India 30:335-355

Tamura K, Peterson D, Peterson N, Stecher G, Nei M, Kumar S (2011). MEGA5: Molecular evolutionary genetics analysis using maximum likelihood, evolutionary distance, and maximum parsimony methods. Mol Biol Evol 28(10):2731-2739

Valett HM, Dahm CN, Campana ME, Morrice JA, Baker MA, Fellows CS (1997) Hydrologic influences on groundwater surface water ecotones: heterogeneity in nutrient composition and retention. J North Am Benthol Soc 16:239-247. doi:10.2307/1468254

Wright MS, Peltier GL, Stepanauskas R, McArthur JV (2006) Bacterial tolerances to metals and antibiotics in metalcontaminated and reference streams. FEMS Microbiol Ecol 58:293-302

Zampieri, BDB, Pinto AB, Schultz L et al (2016) Diversity and Distribution of Heavy Metal-Resistant Bacteria in Polluted Sediments of the Araça Bay, São Sebastião (SP), and the Relationship Between Heavy Metals and Organic Matter Concentrations. Microb Ecol 72:582-594. https://doi.org/10.1007/s00248-016-0821-x

Zeglin LH (2015) Stream microbial diversity in response to environmental changes: review and synthesis of existing research. Front Microbiol 6:454. doi:10.3389/fmicb.2015.00454

Zeng XY, Li SW, Leng Y, Kang XH (2020) Structural and functional responses of bacterial and fungal communities to multiple heavy metal exposure in arid loess. Sci Total Environ 723:138081. doi: 10.1016/j.scitotenv.2020.138081

Zheng B, Lu S, Wu J, Guo X, Wu F, Li W, He Q, Fu Z, Xu L (2018) Heavy metal distribution in Tiaoxi river's sediment. Environ Sci Pollut Res 25:2603-2613

\section{Tables}

Table 1. Site description and location of the sampling sites 


\begin{tabular}{|c|c|c|c|}
\hline $\begin{array}{l}\text { Site } \\
\text { ID }\end{array}$ & $\begin{array}{l}\text { Elevation } \\
(\mathrm{m})\end{array}$ & Coordinates & Site description \\
\hline S1 & 5183 & $\begin{array}{l}\text { N } 28^{\circ} 2.10 .2^{\prime} \\
\mathrm{E} \\
088^{\circ} 42.32 .6^{\prime}\end{array}$ & Uppermost stretch of the river with minimum human interference \\
\hline S2 & 1790 & $\begin{array}{l}\mathrm{N} 27^{\circ} 36.355^{\prime} \\
\mathrm{E} 088^{\circ} 39.062^{\prime}\end{array}$ & $\begin{array}{l}\text { Moderate human settlement with tourism industry and hydro-project in the } \\
\text { vicinity }\end{array}$ \\
\hline T1 & 516 & $\begin{array}{l}\mathrm{N} 27^{\circ} 15.544^{\prime} \\
\mathrm{E} 088^{\circ} 33.118^{\prime}\end{array}$ & $\begin{array}{l}\text { Tributary of river Teesta passing through human settlement and industrial } \\
\text { areas }\end{array}$ \\
\hline S3 & 426 & $\begin{array}{l}\text { N27ำ13.896' } \\
\text { E088 } 29.517^{\prime}\end{array}$ & Site with intense human settlement and mining activities \\
\hline S4 & 333 & $\begin{array}{l}\mathrm{N} 27^{\circ} 10.864^{\prime} \\
\mathrm{E} 088^{\circ} 30.027^{\prime}\end{array}$ & Industrial belt along with human settlement \\
\hline S5 & 295 & $\begin{array}{l}\mathrm{N} 27^{\circ} 04.954^{\prime} \\
\mathrm{E} 088^{\circ} 26.654^{\prime}\end{array}$ & $\begin{array}{l}\text { River banks under forest cover with human settlement and mining } \\
\text { activities }\end{array}$ \\
\hline
\end{tabular}

Table 2. Physico-chemical parameters of the water 


\begin{tabular}{|c|c|c|c|c|c|c|c|c|}
\hline Parameters & & S1 & $\mathrm{S} 2$ & $\mathrm{~T} 1$ & S3 & S4 & S5 & BIS \\
\hline \multirow[t]{2}{*}{ Temperature } & $\mathrm{Mn}$ & $5 \pm 0$ & $17 \pm 0$ & $18 \pm 0$ & $18 \pm 0$ & $18.25 \pm 0.53$ & $18.5 \pm 0.71$ & - \\
\hline & Wn & $2 \pm 0$ & $9 \pm 1.41$ & $14.5 \pm 0.71$ & $14.5 \pm 0.71$ & $15 \pm 1.41$ & $15 \pm 01.41$ & \\
\hline \multirow[t]{2}{*}{$\mathrm{pH}$} & $\mathrm{Mn}$ & $7.4 \pm 0.23$ & $7.59 \pm 0.07$ & $7.71 \pm 0.42$ & $7.29 \pm 0.4$ & $7.75 \pm 0.07$ & $7.53 \pm 0.33$ & $\begin{array}{l}6.5- \\
8.5\end{array}$ \\
\hline & Wn & $7.26 \pm 0.09$ & $7.59 \pm 0.04$ & $7.43 \pm 0.35$ & $7.79 \pm 0.01$ & $7.47 \pm 0.14$ & $7.39 \pm 0.15$ & \\
\hline \multirow[t]{2}{*}{ TDS (ppm) } & $\mathrm{Mn}$ & $26.65 \pm 0.69$ & $25.2 \pm 0.76$ & $25.73 \pm 5.13$ & $28.32 \pm 1.3$ & $26.62 \pm 0.42$ & $25.47 \pm 0.51$ & 500 \\
\hline & Wn & $34.69 \pm 0.26$ & $35.9 \pm 0.67$ & $54.04 \pm 0.91$ & $49.82 \pm 2.49$ & $44.74 \pm 0.78$ & $45.18 \pm 0.35$ & \\
\hline \multirow{2}{*}{$\begin{array}{l}\text { Conductivity } \\
(\mu \mathrm{S} / \mathrm{cm})\end{array}$} & $\mathrm{Mn}$ & $49.92 \pm 1.73$ & $47.20 \pm 1.59$ & $47.11 \pm 10.89$ & $52.64 \pm 2.43$ & $49.52 \pm 0.93$ & $47.45 \pm 0.91$ & 300 \\
\hline & Wn & $62.64 \pm 0.78$ & $66.14 \pm 0.78$ & $99.23 \pm 0.9$ & $91.72 \pm 2.27$ & $82.32 \pm 0.28$ & $85.08 \pm 0.48$ & \\
\hline \multirow[t]{2}{*}{ DO (ppm) } & $\mathrm{Mn}$ & $5.32 \pm 0.17$ & $6.96 \pm 0.79$ & $6.55 \pm 0.78$ & $7.4 \pm 0.06$ & $7.36 \pm 0.09$ & $8.45 \pm 0.3$ & 5 \\
\hline & Wn & $5.05 \pm 0.07$ & $7 \pm 0.28$ & $6.38 \pm 0.2$ & $6.76 \pm 0.06$ & $6.3 \pm 0.42$ & $6.38 \pm 0.09$ & \\
\hline \multirow[t]{2}{*}{ BOD (ppm) } & $\mathrm{Mn}$ & $0.2 \pm 0$ & $0.32 \pm 0.11$ & $1.05 \pm 0.35$ & $3.9 \pm 0.48$ & $0.87 \pm 1.32$ & $1.85 \pm 1.15$ & 5 \\
\hline & $\mathrm{Wn}$ & $0.29 \pm 0.18$ & $1.62 \pm 0.2$ & $2.76 \pm 0.45$ & $1.96 \pm 0.06$ & $2 \pm 0.57$ & $1.18 \pm 0.23$ & \\
\hline
\end{tabular}

Mn-Monsoon; Wn-Winter

Table 3. Heavy metal concentration in the sites during monsoon and winter season 


\begin{tabular}{|c|c|c|c|c|c|}
\hline \multicolumn{6}{|c|}{ Heavy metal concentration in water samples (ppm) } \\
\hline Sampling sites & Seasons & Lead & Zinc & Copper & Cadmium \\
\hline \multirow[t]{2}{*}{ S1 } & $\mathrm{Mn}$ & $0.0048 \pm 0.004$ & $0.0022 \pm 0.004$ & $0.0009 \pm 0.000$ & $0.0002 \pm 0.000$ \\
\hline & Wn & $0.0029 \pm 0.003$ & $0.002 \pm 0.003$ & $0.0005 \pm 0.003$ & $0.0001 \pm 0.000$ \\
\hline \multirow[t]{2}{*}{ S2 } & $\mathrm{Mn}$ & $0.0063 \pm 0.003$ & $0.0139 \pm 0.008$ & $0.0014 \pm 0.003$ & $0.0003 \pm 0.000$ \\
\hline & Wn & $0.0086 \pm 0.003$ & $0.0097 \pm 0.007$ & $0.0015 \pm 0.004$ & $0.0002 \pm 0.000$ \\
\hline \multirow[t]{2}{*}{ T1 } & $\mathrm{Mn}$ & $0.0161 \pm 0.008$ & $0.1007 \pm 0.016$ & $0.0237 \pm 0.018$ & $0.0009 \pm 0.000$ \\
\hline & Wn & $0.014 \pm 0.006$ & $0.0846 \pm 0.009$ & $0.0245 \pm 0.014$ & $0.0005 \pm 0.000$ \\
\hline \multirow[t]{2}{*}{ S3 } & $\mathrm{Mn}$ & $0.0082 \pm 0.004$ & $0.0264 \pm 0.005$ & $0.0041 \pm 0.004$ & $0.0004 \pm 0.000$ \\
\hline & Wn & $0.0033 \pm 0.004$ & $0.0063 \pm 0.002$ & $0.0017 \pm 0.002$ & $0.0002 \pm 0.000$ \\
\hline \multirow[t]{2}{*}{ S4 } & $\mathrm{Mn}$ & $0.0330 \pm 0.021$ & $0.0414 \pm 0.002$ & $0.0056 \pm 0.002$ & $0.0007 \pm 0.000$ \\
\hline & Wn & $0.0046 \pm 0.016$ & $0.007 \pm 0.005$ & $0.0024 \pm 0.000$ & $0.0003 \pm 0.000$ \\
\hline \multirow[t]{2}{*}{ S5 } & $\mathrm{Mn}$ & $0.0149 \pm 0.014$ & $0.0490 \pm 0.0169$ & $0.0102 \pm 0.003$ & $0.0003 \pm 0.000$ \\
\hline & Wn & $0.0112 \pm 0.009$ & $0.0737 \pm 0.021$ & $0.0172 \pm 0.015$ & $0.0006 \pm 0.000$ \\
\hline \multicolumn{2}{|l|}{ BIS } & 0.01 & 15 & 1.5 & 0.003 \\
\hline \multicolumn{6}{|c|}{ Heavy metal concentration in sediment samples (ppm) } \\
\hline \multirow[t]{2}{*}{ S1 } & $\mathrm{Mn}$ & $3.6 \pm 0.002$ & $37.4 \pm 0.018$ & $5.4 \pm 0.002$ & $0.04 \pm 0.000$ \\
\hline & Wn & $5.6 \pm 0.004$ & $1.8 \pm 0.008$ & $1.5 \pm 0.003$ & $0.2 \pm 0.000$ \\
\hline $\mathrm{S} 2$ & $\mathrm{Mn}$ & $8.8 \pm 0.007$ & $53.4 \pm 0.014$ & $8.4 \pm 0.002$ & $0.06 \pm 0.000$ \\
\hline
\end{tabular}




\begin{tabular}{|c|c|c|c|c|c|}
\hline & Wn & $7.7 \pm 0.003$ & $3 \pm 0.015$ & $2 \pm 0.004$ & $0.6 \pm 0.000$ \\
\hline \multirow[t]{2}{*}{ T1 } & $\mathrm{Mn}$ & $11.7 \pm 0.012$ & $55 \pm 0.010$ & $9.4 \pm 0.008$ & $0.17 \pm 0.001$ \\
\hline & Wn & $19.56 \pm 0.042$ & $3.7 \pm 0.003$ & $3.2 \pm 0.002$ & $0.6 \pm 0.000$ \\
\hline \multirow[t]{2}{*}{ S3 } & $\mathrm{Mn}$ & $7.2 \pm 0.005$ & $54.4 \pm 0.011$ & $10.8 \pm 0.005$ & $0.10 \pm 0.000$ \\
\hline & Wn & $12.5 \pm 0.003$ & $2.6 \pm 0.006$ & $3.4 \pm 0.012$ & $0.5 \pm 0.000$ \\
\hline \multirow[t]{2}{*}{ S4 } & $\mathrm{Mn}$ & $27.4 \pm 0.017$ & $83 \pm 0.012$ & $12.7 \pm 0.015$ & $0.65 \pm 0.004$ \\
\hline & Wn & $14.8 \pm 0.006$ & $6 \pm 0.017$ & $9.2 \pm 0.006$ & $1.2 \pm 0.001$ \\
\hline \multirow[t]{2}{*}{ S5 } & $\mathrm{Mn}$ & $21.0 \pm 0.042$ & $85.6 \pm 0.026$ & $11.2 \pm 0.007$ & $0.21 \pm 0.001$ \\
\hline & Wn & $19.56 \pm 0.042$ & $3.7 \pm 0.003$ & $3.2 \pm 0.002$ & $0.6 \pm 0.000$ \\
\hline IRS & & 11 & 16 & 28 & - \\
\hline
\end{tabular}

Mn-Monsoon; Wn-Winter

Table 4. Total viable bacterial count

\begin{tabular}{|c|c|c|c|c|c|c|}
\hline \multirow[t]{3}{*}{ Season } & \multicolumn{6}{|c|}{$\begin{array}{l}\text { Average } \mathrm{CFU} / \mathrm{ml} \text { in the samples } \\
\text { CFU } \times 10^{4}\end{array}$} \\
\hline & S1 & S2 & $\mathrm{T} 1$ & S3 & S4 & S5 \\
\hline & \multicolumn{6}{|c|}{ WATER SAMPLE } \\
\hline Monsoon & $3.1 \pm 0.35$ & $15.56 \pm 2.6$ & $28.8 \pm 3.4$ & $19 \pm 1.35$ & $25.2 \pm 6.36$ & $24.1 \pm 2.5$ \\
\hline \multirow[t]{2}{*}{ Winter } & $2.8 \pm 0.9$ & $7.6 \pm 0.9$ & $11 \pm 1.78$ & $7.7 \pm 0.9$ & $9.7 \pm 2.12$ & $8.5 \pm 0.9$ \\
\hline & \multicolumn{6}{|c|}{ SEDIMENT SAMPLE } \\
\hline Monsoon & $4.6 \pm 0.9$ & $96 \pm 28.6$ & $115 \pm 27.5$ & $123 \pm 20.4$ & $165 \pm 9.5$ & $111 \pm 25.5$ \\
\hline Winter & $4.4 \pm 1.3$ & $141 \pm 30.3$ & $156 \pm 11$ & $163 \pm 23.0$ & $175 \pm 22.0$ & $155 \pm 8.0$ \\
\hline
\end{tabular}

The values represent the average of three replicates with standard deviation 
Table 5. Various indices calculated for water and sediment samples

\begin{tabular}{|c|c|c|c|c|c|c|c|c|c|c|c|c|}
\hline \multirow[t]{3}{*}{ Diversity indices } & \multicolumn{12}{|c|}{ Water sample } \\
\hline & \multicolumn{6}{|c|}{ Monsoon } & \multicolumn{6}{|c|}{ Winter } \\
\hline & S1 & $\mathrm{S} 2$ & $\mathrm{~T} 1$ & S3 & S4 & S5 & S1 & $\mathrm{S} 2$ & T1 & S3 & S4 & S5 \\
\hline Shannon & 1.76 & 1.91 & 2.63 & 2.67 & 2.71 & 2.91 & 1.96 & 2.01 & 2.13 & 2.68 & 2.19 & 2.74 \\
\hline Simpson & 1 & 0.77 & 0.97 & 0.94 & 0.95 & 0.97 & 0.89 & 1 & 0.9 & 0.98 & 0.93 & 0.97 \\
\hline Margalef & 2.16 & 2.65 & 3.62 & 3.88 & 3.81 & 4.50 & 2.28 & 2.50 & 2.61 & 3.75 & 2.61 & 3.90 \\
\hline Evenness & 1.46 & 0.85 & 1.39 & 1.2 & 1.25 & 1.32 & 1.18 & 1.50 & 1.21 & 1.46 & 1.27 & 1.40 \\
\hline \multirow[t]{3}{*}{ Diversity indices } & \multicolumn{12}{|c|}{ Sediment sample } \\
\hline & \multicolumn{6}{|c|}{ Monsoon } & \multicolumn{6}{|c|}{ Winter } \\
\hline & S1 & $\mathrm{S} 2$ & $\mathrm{~T} 1$ & S3 & S4 & S5 & S1 & S2 & T1 & S3 & S4 & S5 \\
\hline Shannon & 1.03 & 2.11 & 2.29 & 2.05 & 1.89 & 1.89 & 1.89 & 1.84 & 2.47 & 2.21 & 2.04 & 1.38 \\
\hline Simpson & 0.6 & 0.95 & 0.93 & 0.93 & 0.93 & 0.93 & 0.93 & 0.91 & 0.96 & 0.96 & 0.87 & 0.75 \\
\hline Margalef & 1.12 & 2.57 & 2.92 & 2.40 & 2.23 & 2.23 & 2.23 & 2.06 & 3.22 & 2.89 & 2.50 & 1.37 \\
\hline Evenness & 0.94 & 1.37 & 1.24 & 1.29 & 1.33 & 1.33 & 1.33 & 1.25 & 1.32 & 1.40 & 1.09 & 0.99 \\
\hline
\end{tabular}

Table 6. Spearmen correlation between the Shannon species diversity for water (SDW) and Bacterial load for water (BLW) with different pysio-chemical parameters and heavy metal concentration in the water samples.

\begin{tabular}{|c|c|c|c|c|c|c|c|c|c|c|}
\hline & & SDW & BLW & Temp & $\mathrm{pH}$ & TDS & $\mathrm{Pb}$ & $\mathrm{Zn}$ & $\mathrm{Cu}$ & $\mathrm{Cd}$ \\
\hline \multirow[t]{2}{*}{ SDW } & Correlation Coefficient & 1.000 & $.690^{*}$ & $.675^{\star}$ & .294 & .063 & .503 & .517 & $.643^{\star}$ & .504 \\
\hline & Sig. (2-tailed) & . & .013 & .016 & .354 & .846 & .095 & .085 & .024 & .095 \\
\hline \multirow[t]{2}{*}{ BLW } & Correlation Coefficient & $.690^{*}$ & 1.00 & $.806^{\star *}$ & .357 & -.175 & $.795^{\star \star}$ & $.771^{\star *}$ & $.830^{\star \star}$ & $.814^{\star \star}$ \\
\hline & Sig. (2-tailed) & .013 & . & .002 & .254 & .586 & .002 & .003 & .001 & .001 \\
\hline
\end{tabular}

*. Correlation is significant at the 0.05 level (2-tailed).

**. Correlation is significant at the 0.01 level (2-tailed).

Table 7. Spearmen correlation between the Shannon species diversity for sediment (SDS) and Bacterial load for sediment (BLS) with various physico-chemical parameters and heavy metal concentrations

*. Correlation is significant at the 0.05 level (2-tailed).

**. Correlation is significant at the 0.01 level (2-tailed). 


\begin{tabular}{|clllllll|l|}
\hline \multirow{2}{*}{ SDS } & & SDS & BLS & $\mathrm{Pb}$ & $\mathrm{Zn}$ & $\mathrm{Cu}$ & $\mathrm{Cd}$ & $\begin{array}{l}\text { Table 8. Tolerance of the isolates } \\
\text { to heavy metals }\end{array}$ \\
\cline { 2 - 9 } & Correlation Coefficient & 1.000 & .239 & .120 & .021 & .070 & -.081 \\
\multirow{2}{*}{ BLS } & Sig. (2-tailed) & Correlation Coefficient &. & .454 & .711 & .948 & .828 & .802 \\
\cline { 2 - 8 } & Sig. (2-tailed) & .454 & 1.000 & $.664^{\star}$ & -.042 & .217 & $.813^{\text {** }}$ \\
\hline
\end{tabular}




\begin{tabular}{|c|c|c|c|c|c|c|c|}
\hline \multirow[t]{2}{*}{ Sites } & \multirow[t]{2}{*}{$\begin{array}{l}\text { No of } \\
\text { isolates }\end{array}$} & \multicolumn{6}{|c|}{$\begin{array}{l}\text { Heavy metal concentration in ppm with number of isolates having corresponding MIC } \\
\text { values }\end{array}$} \\
\hline & & 50 & 100 & 250 & 500 & 1000 & 2000 \\
\hline \multicolumn{8}{|l|}{ Lead } \\
\hline S1 & 5 & & & & 2 & 3 & 0 \\
\hline S2 & 18 & & & & & 2 & 16 \\
\hline T1 & 21 & & & & 1 & 0 & 20 \\
\hline S3 & 14 & & & & & 2 & 12 \\
\hline S4 & 26 & & & & & 7 & 19 \\
\hline S5 & 23 & & & & & 2 & 21 \\
\hline \multicolumn{8}{|l|}{ Zinc } \\
\hline S1 & 5 & & & 5 & & & \\
\hline S2 & 18 & & 2 & 10 & 4 & 2 & \\
\hline T1 & 21 & & 1 & 11 & 9 & & \\
\hline S3 & 14 & & & 8 & 4 & 2 & \\
\hline S4 & 26 & & 4 & 1 & 15 & 6 & \\
\hline S5 & 23 & & & 6 & 13 & 4 & \\
\hline \multicolumn{8}{|c|}{ Copper } \\
\hline S1 & 5 & & & 5 & & & \\
\hline S2 & 18 & & & 4 & 14 & & \\
\hline T1 & 21 & & & 12 & 9 & & \\
\hline S3 & 14 & & & & 12 & 2 & \\
\hline S4 & 26 & & & 3 & 17 & 6 & \\
\hline S5 & 23 & & & 3 & 20 & & \\
\hline \multicolumn{8}{|c|}{ Cadmium } \\
\hline & & 1 & 2.5 & 5 & 10 & 50 & 100 \\
\hline S1 & 5 & & & & 5 & & \\
\hline S2 & 18 & & & 1 & & 9 & 8 \\
\hline T1 & 21 & & 1 & 1 & 8 & 7 & 4 \\
\hline S3 & 14 & & & & 2 & 7 & 5 \\
\hline S4 & 26 & & & & 1 & 16 & 10 \\
\hline S5 & 23 & & & & 2 & 2 & 19 \\
\hline
\end{tabular}


Table 9. No of isolates showing resistance to the antibiotics

\begin{tabular}{|c|c|c|c|c|c|c|c|}
\hline \multirow[t]{3}{*}{ Antibiotic class } & \multirow[t]{3}{*}{ Antibiotics } & \multicolumn{6}{|c|}{ Number of isolates resistant to antibiotics at each site } \\
\hline & & S1 & S2 & S3 & S4 & S5 & T1 \\
\hline & & $n=5$ & $\mathrm{n}=18$ & $\mathrm{n}=14$ & $n=26$ & $n=23$ & $\mathrm{n}=21$ \\
\hline \multirow[t]{2}{*}{ B-lactams } & MRP & 0 & 0 & 0 & 0 & 0 & 0 \\
\hline & I & 0 & 1 & 1 & 13 & 3 & 0 \\
\hline \multirow[t]{2}{*}{ Quinolone } & NA & 4 & 5 & 3 & 1 & 9 & 10 \\
\hline & $\mathrm{CIP}$ & 0 & 0 & 0 & 0 & 4 & 0 \\
\hline \multirow[t]{3}{*}{ Aminoglycosides } & NET & 0 & 0 & 0 & 6 & 2 & 0 \\
\hline & $\mathrm{N}$ & 0 & 0 & 0 & 0 & 2 & 3 \\
\hline & NV & 0 & 9 & 9 & 18 & 11 & 3 \\
\hline Macrolide & $\mathrm{E}$ & 0 & 7 & 9 & 11 & 7 & 9 \\
\hline Sulfonamide & COT & 0 & 4 & 9 & 13 & 7 & 8 \\
\hline Cephalosporin & $\mathrm{CA}$ & 4 & 16 & 14 & 24 & 19 & 19 \\
\hline Polypeptide & PB & 0 & 2 & 3 & 6 & 10 & 7 \\
\hline Polyketide & RIF & 2 & 9 & 10 & 21 & 17 & 6 \\
\hline Glycylcycline & TGC & 0 & 0 & 0 & 0 & 0 & 3 \\
\hline Antifolate & $\mathrm{TR}$ & 1 & 7 & 9 & 12 & 12 & 1 \\
\hline Lincosamide & $\mathrm{L}$ & 1 & 17 & 11 & 14 & 11 & 14 \\
\hline
\end{tabular}

MRP-Meropenem, I- Imepenem, NA- Nalidixic acid, CIP- Ciprofloxacin, NET- Netillin, N-Neomycin, NV- Novobiocin, EErythromycin, COT- Co-trimoxazole, CA- Ceftazidime, PB- Polymyxin B, RIF- Rifampicin, TGC- Tigecycline, TRTrimethoprim, L- Lincomycin

Table 10. Antibiotic resistance profile of the isolates 


\begin{tabular}{|c|c|c|c|c|c|c|c|c|c|c|c|c|}
\hline \multirow[t]{2}{*}{ Sites } & \multirow[t]{2}{*}{$\begin{array}{l}\text { No. of } \\
\text { isolates }\end{array}$} & \multicolumn{10}{|c|}{$\begin{array}{l}\text { Number of isolates showing resistance to corresponding } \\
\text { number of antibiotics }\end{array}$} & \multirow[t]{2}{*}{$\begin{array}{l}\text { Percentage of MAR } \\
\text { bacteria at each site }\end{array}$} \\
\hline & & 1 & 2 & 3 & 4 & 5 & 6 & 7 & 8 & 9 & $\begin{array}{l}\text { MAR index } \\
\text { range }\end{array}$ & \\
\hline S1 & 5 & 5 & 3 & 2 & & & & & & & $0.13-0.2$ & Nil \\
\hline S2 & 18 & 17 & 17 & 14 & 11 & 6 & 5 & 4 & 1 & 1 & $0-0.46$ & 61 \\
\hline T1 & 21 & 21 & 20 & 15 & 13 & 6 & 3 & 3 & 3 & - & $0.13-0.53$ & 62 \\
\hline S3 & 14 & 14 & 14 & 13 & 9 & 9 & 9 & 9 & 1 & - & $0.2-0.53$ & 64 \\
\hline S4 & 26 & 26 & 26 & 24 & 24 & 17 & 8 & 8 & 6 & - & $0.13-0.53$ & 92 \\
\hline S5 & 23 & 23 & 23 & 23 & 22 & 18 & 3 & 2 & - & - & $0.2-0.46$ & 95 \\
\hline
\end{tabular}

\section{Figures}

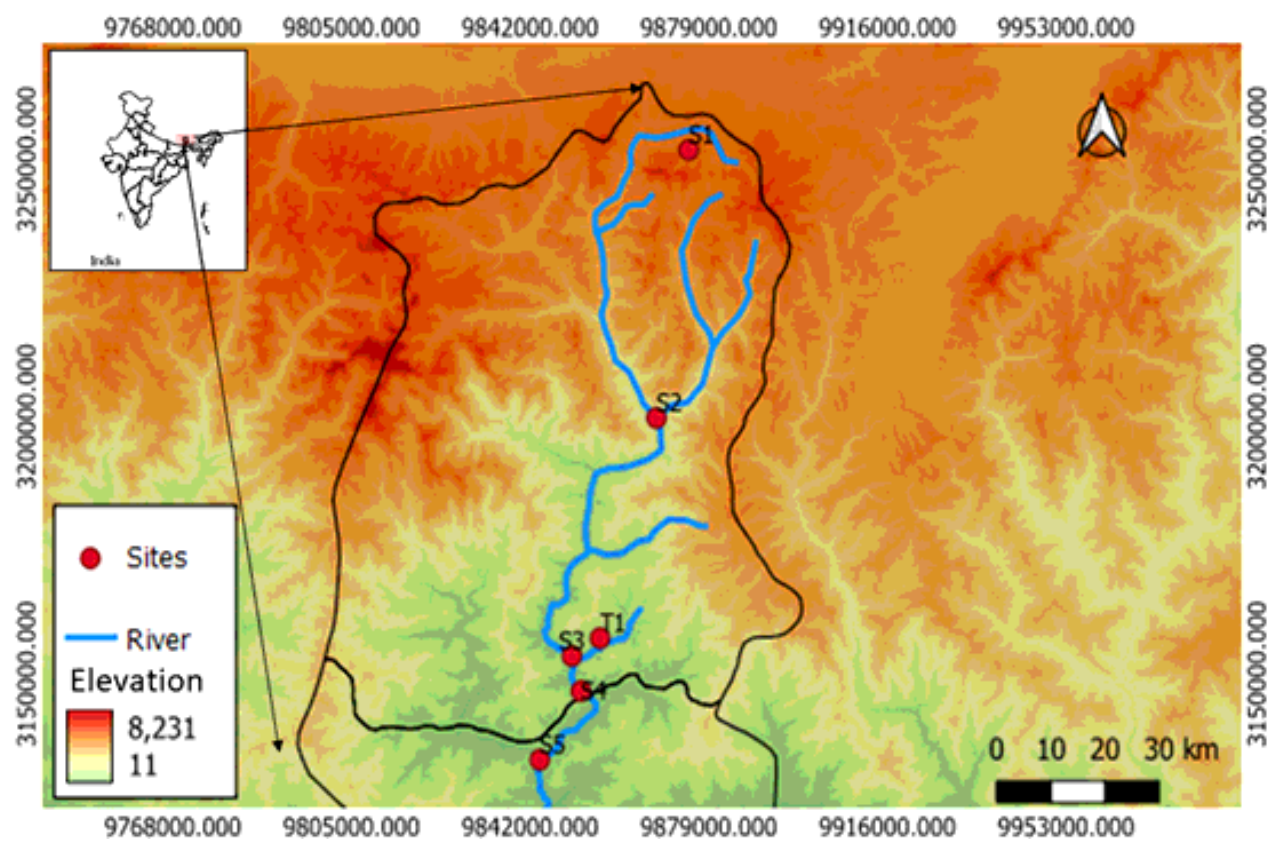

Figure 1

Map of Study area 

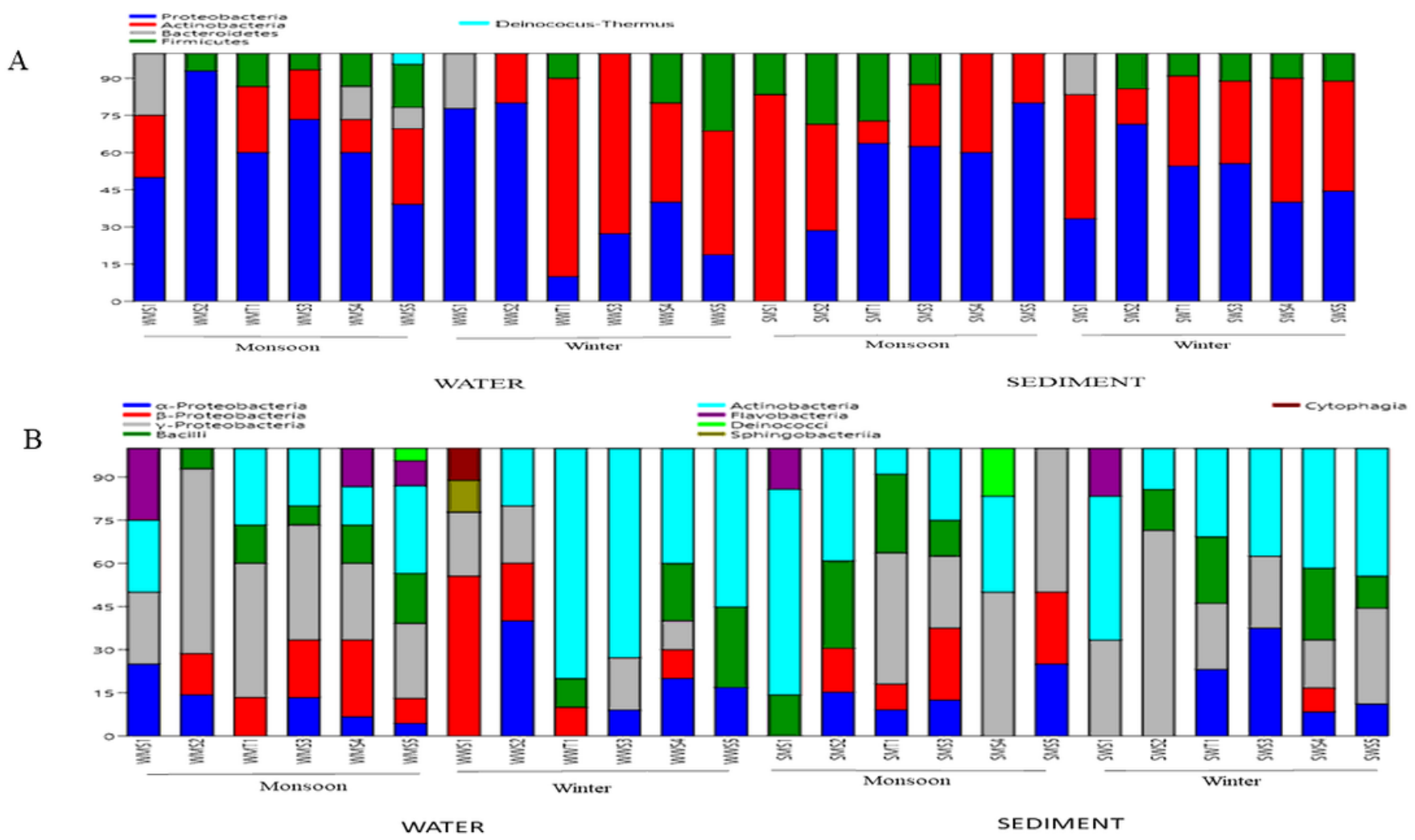

Figure 2

Graphical representation of bacterial diversity at phylum (A) and class (B) level for the water and sediment samples 
A B

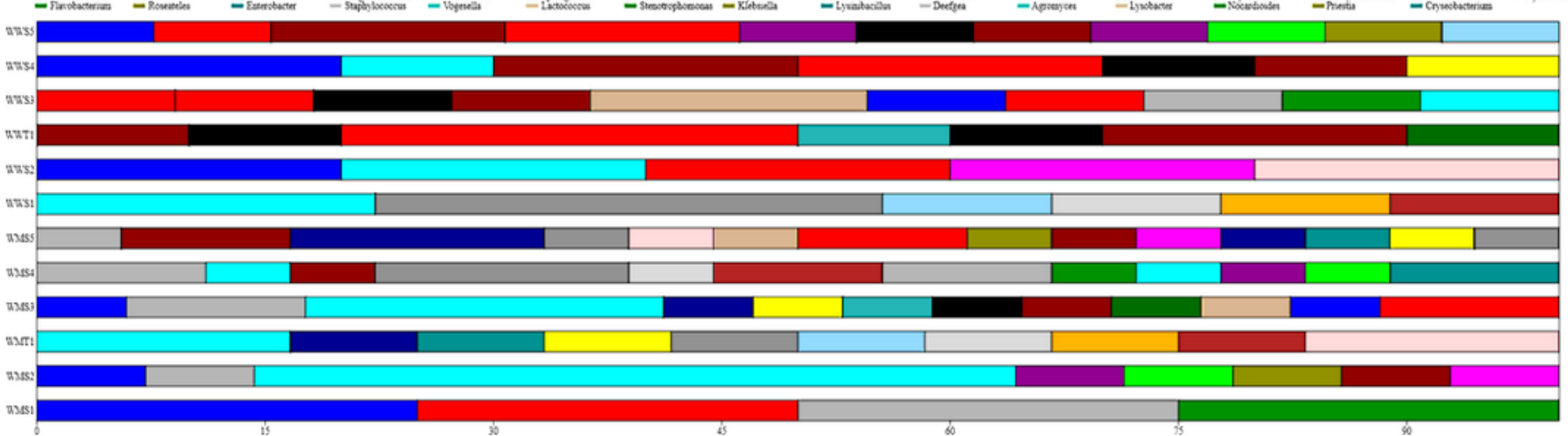

B

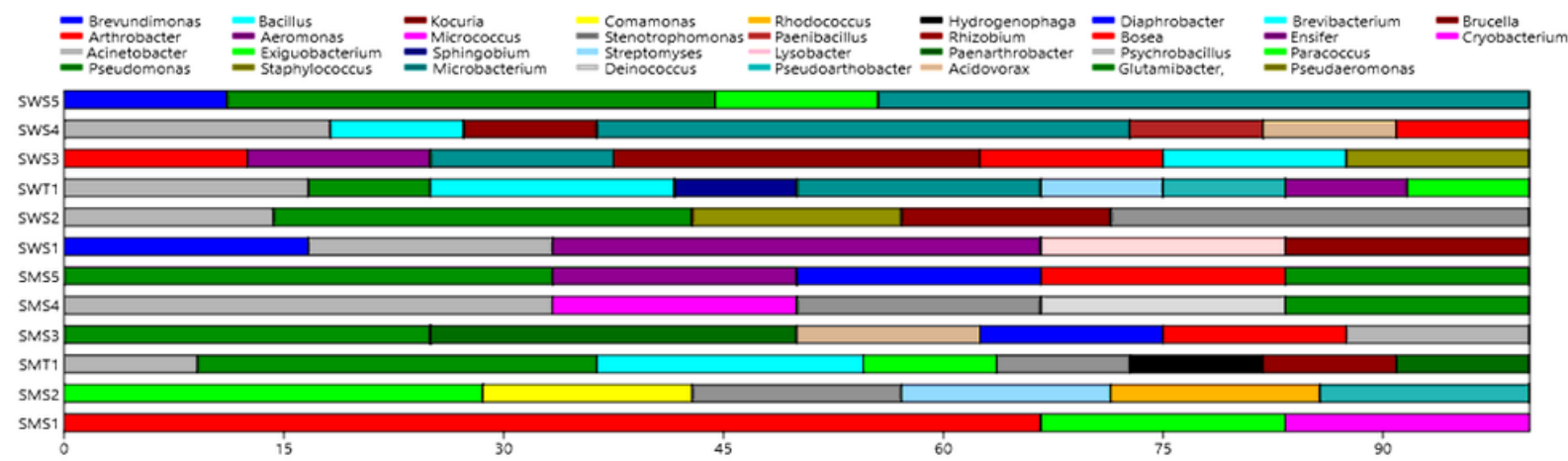

\section{Figure 3}

Graphical representation of various genera identified in water and sediment samples

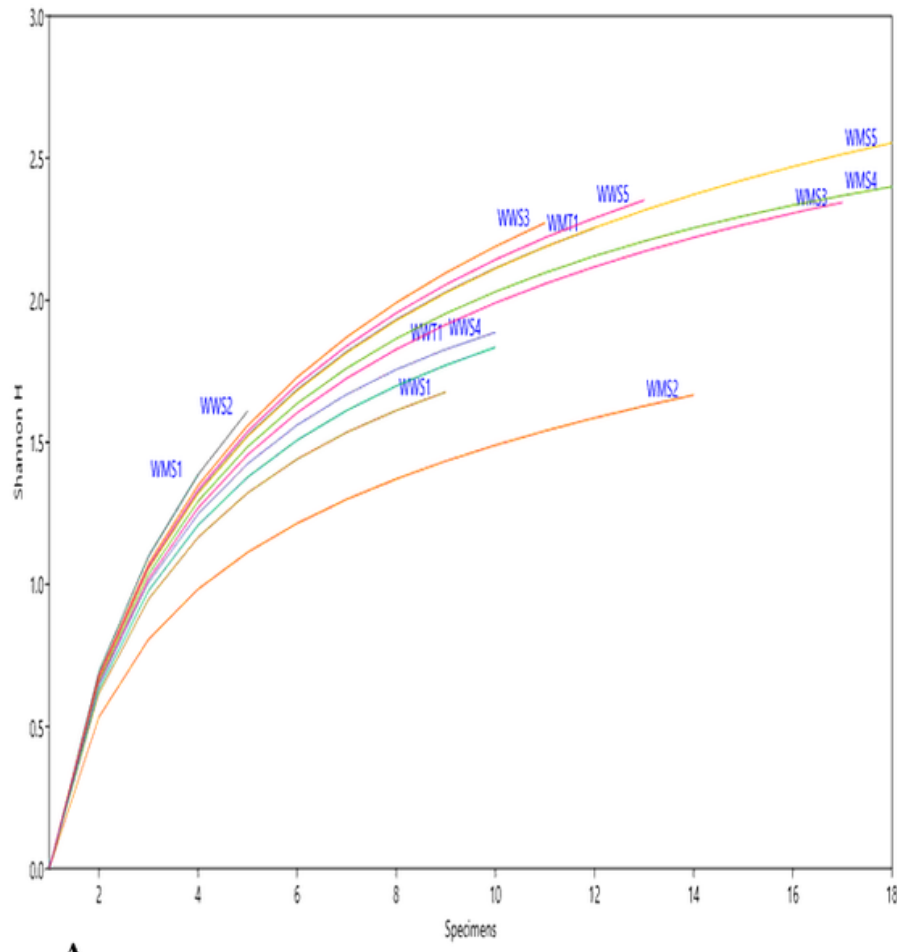

A

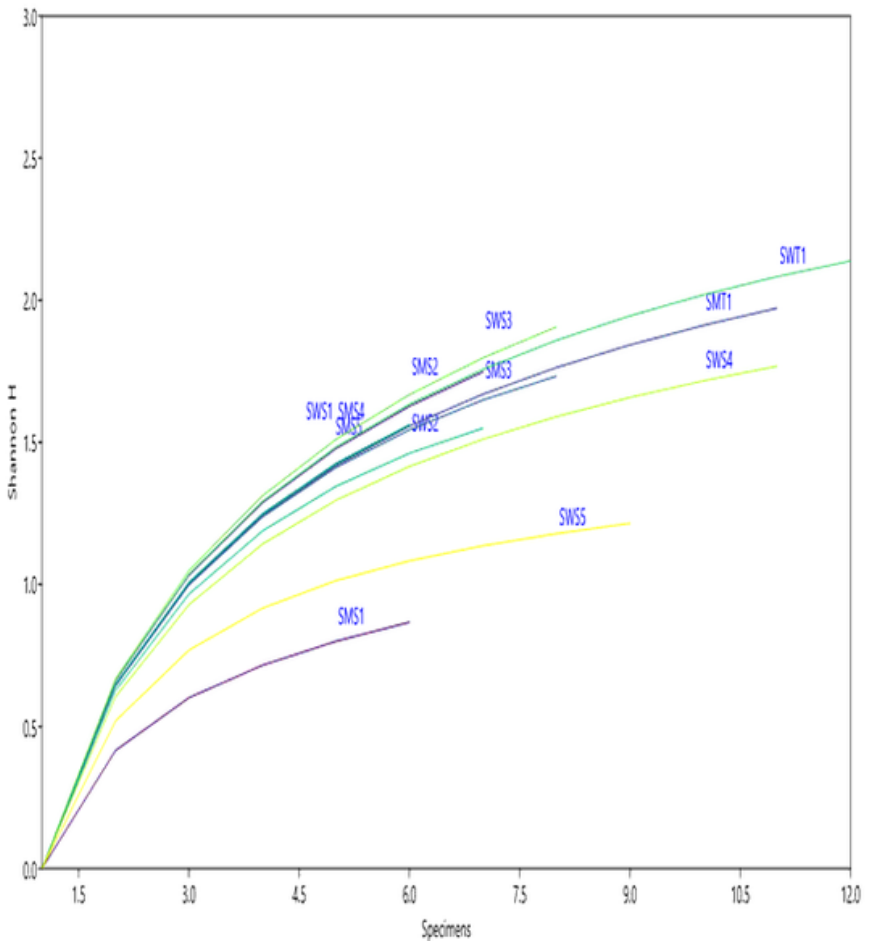

B

Figure 4 

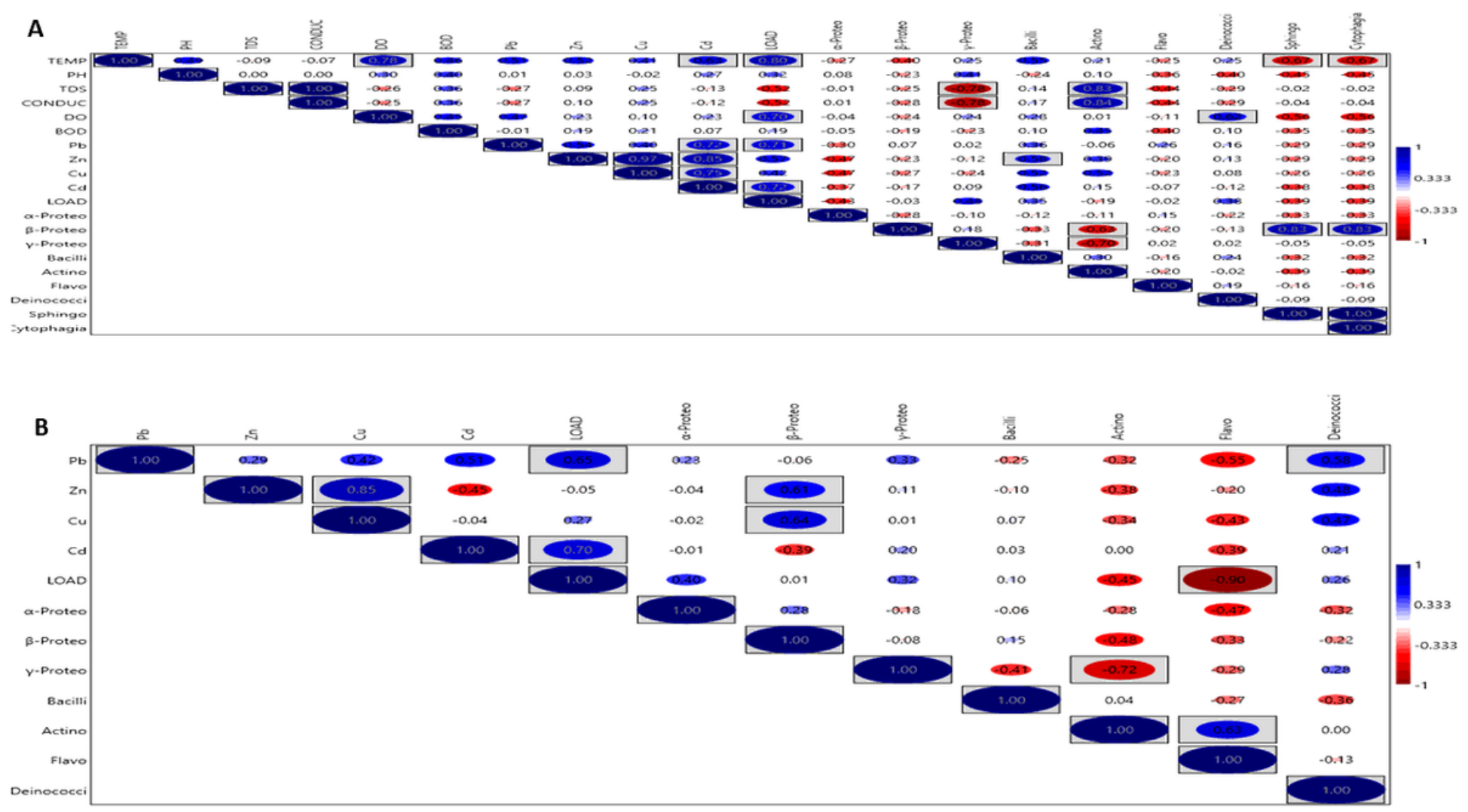

Figure 5

Pearson's correlation coefficient rank between and among the physico-chemical properties of water (A) and sediment (B) and bacterial taxa abundances. The values in the box represent the level of significance $(p<0.05)$.

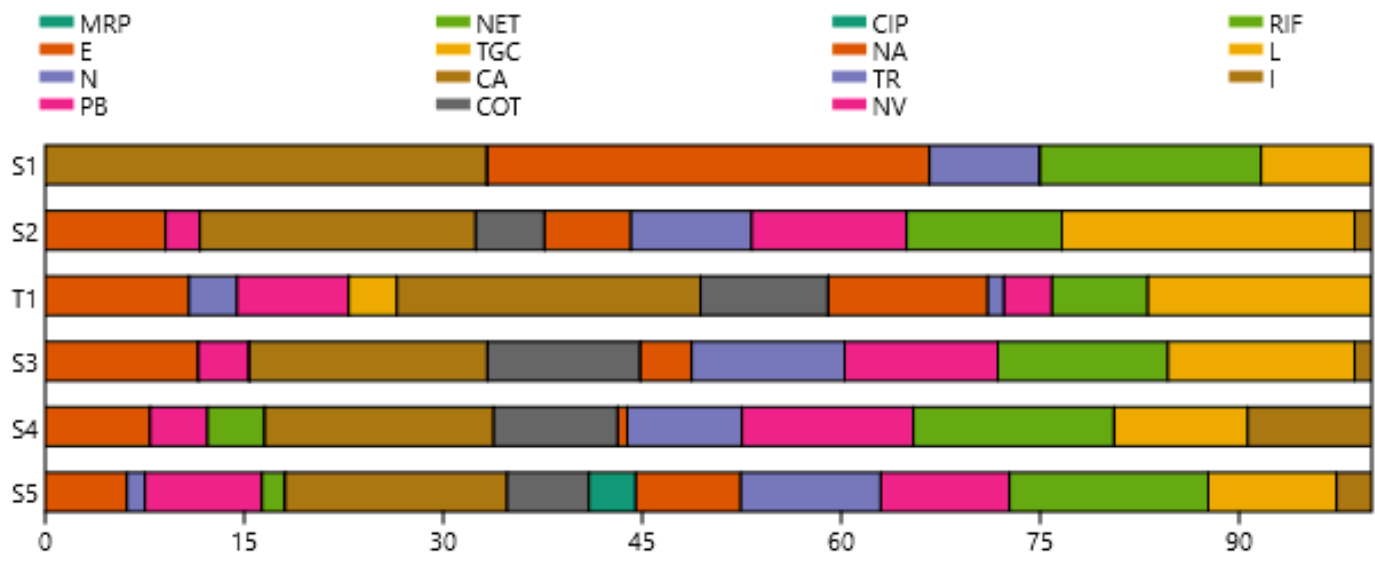

\section{Figure 6}

Graphical representation of the percentage of isolates resistant to various antibiotics at each sites 